\title{
Glyphosate (Ab)sorption by Shoots and Rhizomes of Native versus Hybrid Cattail (Typha)
}

\author{
Tianye Zheng ${ }^{1,2} \oplus \cdot$ Nora B. Sutton ${ }^{2} \cdot$ Pim de Jager $^{2} \cdot$ Richard Grosshans $^{3} \cdot$ \\ Sirajum Munira ${ }^{4} \cdot$ Annemieke Farenhorst $^{4}$
}

Received: 8 May 2017 / Accepted: 22 August 2017 / Published online: 14 September 2017

(c) The Author(s) 2017. This article is an open access publication

\begin{abstract}
Wetlands in the Prairie Pothole Region of North America are integrated with farmland and contain mixtures of herbicide contaminants. Passive nonfacilitated diffusion is how most herbicides can move across plant membranes, making this perhaps an important process by which herbicide contaminants are absorbed by wetland vegetation. Prairie wetlands are dominated by native cattail (Typha latifolia) and hybrid cattail (Typha $x$ glauca). The objective of this batch equilibrium study was to compare glyphosate absorption by the shoots and rhizomes of native versus hybrid cattails. Although it has been previously reported for some pesticides that passive diffusion is greater for rhizome than shoot components, this is the first study to demonstrate that the absorption capacity of rhizomes is species dependent, with the glyphosate absorption being significantly greater for rhizomes than shoots in case of native cattails, but with no significant differences in glyphosate absorption between rhizomes and shoots in case of hybrid cattails. Most importantly, glyphosate absorption by native rhizomes far exceeded that of the absorption occurring for hybrid rhizomes, native shoots and hybrid shoots. Glyphosate has long been used to manage invasive hybrid cattails in wetlands in
\end{abstract}

Tianye Zheng

darren.t.zheng@polyu.edu.hk

1 Department of Electrical Engineering, The Hong Kong Polytechnic University, Kowloon, Hong Kong

2 Sub-department of Environmental Technology, Wageningen University and Research Centre, Bornse Weilanden 9, Wageningen, The Netherlands

3 International Institute for Sustainable Development (IISD), 111 Lombard Avenue, Suite 325, Winnipeg, MB, Canada

4 Department of Soil Science, University of Manitoba, 380 Ellis Building, Winnipeg, MB, Canada
North America, but hybrid cattail expansions continue to occur. Since our results showed limited glyphosate absorption by hybrid shoots and rhizomes, this lack of sorption may partially explain the poorer ability of glyphosate to control hybrid cattails in wetlands.

Keywords Phytoremediation - Wetland pollution - Native cattail $\cdot$ Hybrid cattail $\cdot$ Glyphosate $\cdot$ Sorption

Pesticide contamination in surface water has been frequently reported (Hiller et al. 2008; Messing et al. 2013, 2014b; Richards and Baker 1993). Glyphosate [ $N$ (phosphonomethyl) glycine] and MCPA (2-methyl-4-chlorophenoxyacetic acid) are among the most widely applied herbicides in North American agriculture, and are frequently detected in surface waters, particularly in wetlands that are integrated with farmland in the Prairie Pothole Region of North America (Benbrook 2016; Farenhorst et al. 2015a, b; Messing et al. 2014a; Schrübbers et al. 2016). Prairie wetlands are contaminated with a range of pesticides that can enter wetlands because of spray drift, atmospheric wet and dry deposition, gas exchanges at the air-water interface, surface runoff and groundwater recharge (Messing et al. 2011; Waite et al. 1992, 1995). The concentrations of individual pesticides detected in Prairie wetlands are typically in the parts per billion range with a reported maximum detection of $9 \mu \mathrm{g} / \mathrm{L}$ for MCPA (Donald et al. 1999). In surface waters, pesticides can be present in the parts per million range with reported maximum detections of $1.48 \mathrm{mg} / \mathrm{L}$ for glyphosate (Mayakaduwa et al. 2016) and of $0.29 \mathrm{mg} / \mathrm{L}$ for other pesticides including MCPA (Ignatowicz 2009).

Conventional physical and chemical technologies for removing contaminants from surface water aim at removal before utilization, for example, flocculation, membrane 
Table 1 Physical-chemical properties of glyphosate (Franz et al. 1997) and MCPA (Hiller et al. 2008)

\begin{tabular}{lllll}
\hline Herbicides & $\begin{array}{l}\text { Molecular } \\
\text { weight }(\mathrm{g} / \mathrm{mol})\end{array}$ & $\begin{array}{l}\text { Solubility in } \\
\text { water at } 25{ }^{\circ} \mathrm{C} \\
(\mathrm{mg} / \mathrm{L})\end{array}$ & $\begin{array}{l}\text { Octanol-water parti- } \\
\text { tion coefficient }(\mathrm{log} \\
\left.\mathrm{K}_{\mathrm{ow}}\right)\end{array}$ & Chemical structure \\
\hline Glyphosate & 169.1 & 12,000 & -3.40 &
\end{tabular}

filtration (Shkinev 2001). Some technologies can be effective (e.g. reverse osmosis, chemical precipitation), but with high investment and operational costs (Olette et al. 2008; Pearson 2001). Consequently, these technologies are typically applied for producing potable water, not for mitigating surface water quality. Phytoremediation within the context of (constructed) wetlands is an alternative technique that can be applied to mitigate the concentrations of a range of contaminants in water including pesticides, nutrients, heavy metals, and pharmaceuticals (Dosnon-Olette et al. 2009). These more nature-based technologies have the advantages of being low cost, easy to operate and having a low environmental impact. In previous studies, the capacity of some aquatic plants (e.g. duckweed) and algae species to absorb organic contaminants has been investigated (Dosnon-Olette et al. 2010a, b). Less information (Moore et al. 2013) is available on cattail (Typha) species, which is notable, considering that these plants often dominate wetlands. Prairie wetlands in North America are dominated by a mix of native cattail (Typha latifolia), the European introduced cattail (Typha $x$ angustifolia) and hybrid cattail (Typha $x$ glauca) from the two parent species. The native (Typha latifolia) and the hybrid species (Typha $x$ glauca) were chosen to be tested in this study.

Since the primary pathway for organic contaminants to enter plants is via passive absorption (Li et al. 2005; Ma and Wang 2009), it is crucial to understand the sorption characteristics of different species of cattails. The objective of this batch equilibrium study was to investigate the absorption of glyphosate and MCPA by the shoots and rhizomes of native versus hybrid cattails. These results can provide important information on the removal of pesticides by different cattail tissues as well as giving an indication of the susceptibility of cattail species towards pesticides.

\section{Materials and Methods}

Herbicides purchased were [phosphonomethyl-14C] glyphosate $(99 \%$ radiochemical purity; specific activity $50 \mathrm{mCi} /$ mmol) and [2-methyl-4-chlorophenoxyacetic acid ${ }^{14} \mathrm{C}$ ] MCPA (98\% radiochemical purity; specific activity $55 \mathrm{mCi} /$ mmol) from American Radiolabeled Chemicals Inc., USA, and analytical grade glyphosate (99.9\% purity) and MCPA (99\% purity) from Sigma-Aldrich Co., St. Louis, MO, USA. Glyphosate and MCPA properties are given in Table 1. The native cattail species was collected from a wetland located in the Experimental Lakes Area (ELA) of the Province of Ontario, Canada. The hybrid cattail species was collected from the constructed wetland named Pelly's Lake located in the Province of Manitoba, Canada. The cattail plant samples were separated into native shoots, native rhizomes, hybrid shoots and hybrid rhizomes and then oven-dried $\left(65^{\circ} \mathrm{C}\right)$ for $72 \mathrm{~h}$ and pulverized using a grinder.

Glyphosate stock solutions consisted of $10 \mu \mathrm{g} / \mathrm{L}$ or $1 \mathrm{mg} / \mathrm{L}$ analytical-grade glyphosate and $6.67 \times 10^{4} \mathrm{~Bq} / \mathrm{L}$ ${ }^{14} \mathrm{C}$-labelled glyphosate. MCPA stock solutions consisted of $10 \mu \mathrm{g} / \mathrm{L}$ or $1 \mathrm{mg} / \mathrm{L}$ analytical-grade MCPA and $1.67 \times 10^{4}$ $\mathrm{Bq} / \mathrm{L}{ }^{14} \mathrm{C}$-labelled MCPA. We included MCPA in this study so that we could compare the sorption of glyphosate against that of another herbicide that is frequently detected in Prairie wetlands. Solutions $(15 \mathrm{~mL})$ were added to $0.2 \mathrm{~g}$ plant samples in $50 \mathrm{~mL}$ Teflon tube in triplicates, and a previous batch equilibrium study (Trapp and Miglioranza 2001) has used a similar plant to solution ratio. Slurries were rotated at $5{ }^{\circ} \mathrm{C}$ in the dark for $0.5,1,2,4,8,24$, and $48 \mathrm{~h}$ to determine the absorption of glyphosate over time.

For MCPA, only the $48 \mathrm{~h}$ time step was used since the absorption was too weak to be analyzed over time. At each time, tubes were centrifuged at 10,000 rpm for $10 \mathrm{~min}$ and subsamples $(1 \mathrm{~mL})$ of supernatant (duplicates) were added 
to scintillation vials $(7 \mathrm{~mL})$ containing $5 \mathrm{~mL} 30 \%$ Scintisafe scintillation cocktail (Fisher Scientific, Fair Lawn, NJ). Vials were lightly shaken before radioactivity was measured. The radioactivity in the initial solution and centrifuged supernatant were measured by Liquid Scintillation Counting (LSC) with automated quench correction (\#H method) (LS 6500 Beckman Instruments, Fullerton, CA) and a maximum counting time of $10 \mathrm{~min}$.

The plant-solution partition coefficients $\mathrm{K}_{\mathrm{pl}}(\mathrm{L} / \mathrm{kg})$ of glyphosate or MCPA was calculated by:

$K_{p l}=\frac{\left(C_{i} \times V-C_{e} \times V\right) / W_{p l}}{C_{e}}$

where $\mathrm{C}_{\mathrm{i}}$ is the concentration of radioactivity in the initial solution; $\mathrm{C}_{\mathrm{e}}$ is the concentration of radioactivity in the
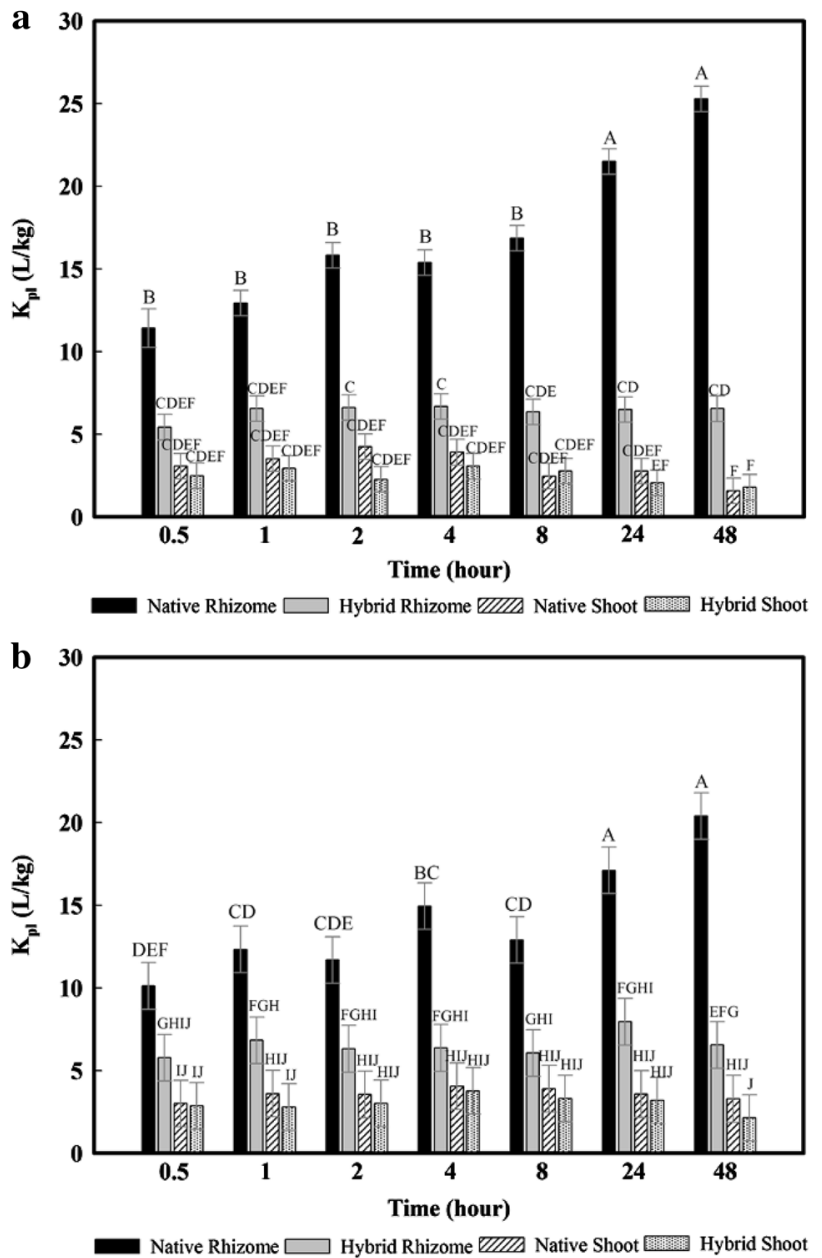

Fig. 1 Time dependent sorption study of the plant-solution partition coefficient $\left(\mathrm{K}_{\mathrm{pl}}\right)$ of glyphosate at the initial concentration of a $10 \mu \mathrm{g} / \mathrm{L}$ and $\mathbf{b} 1 \mathrm{mg} / \mathrm{L}$; the $\mathrm{K}_{\mathrm{pl}}$ values were calculated by taking the average of the triplicate and the error bars indicated the standard deviation; the letters obtained from statistical analysis indicate the significance between the $\mathrm{K}_{\mathrm{pl}}$ values centrifuged supernatant; $\mathrm{V}$ is the volume of solution; $\mathrm{W}_{\mathrm{pl}}$ is the oven-dry weight of plant sample.

Statistical analysis was conducted by using SAS software version 9.3 for Windows (SAS Institute Inc. 2002-2010). Repeated measure analysis and multiple means comparison (Tukey's) tests were utilized in PROC GLIMMIX to determine the effect of shaking time and plant treatment on $\mathrm{K}_{\mathrm{pl}}$ values. Two-way ANOVA in PROC GLIMMIX was used to quantify the effect of concentrations $(10 \mu \mathrm{g} / \mathrm{L}, 1 \mathrm{mg} / \mathrm{L})$ and plant treatments (native shoots, native rhizomes, hybrid shoots, hybrid rhizomes) on $\mathrm{K}_{\mathrm{pl}}$ values at $48 \mathrm{~h}$.

\section{Results and Discussion}

Regardless of whether the initial solution contained $10 \mu \mathrm{g} / \mathrm{L}$ or $1 \mathrm{mg} / \mathrm{L}$ glyphosate, native rhizomes always demonstrated significantly greater glyphosate $\mathrm{K}_{\mathrm{pl}}$ values than hybrid
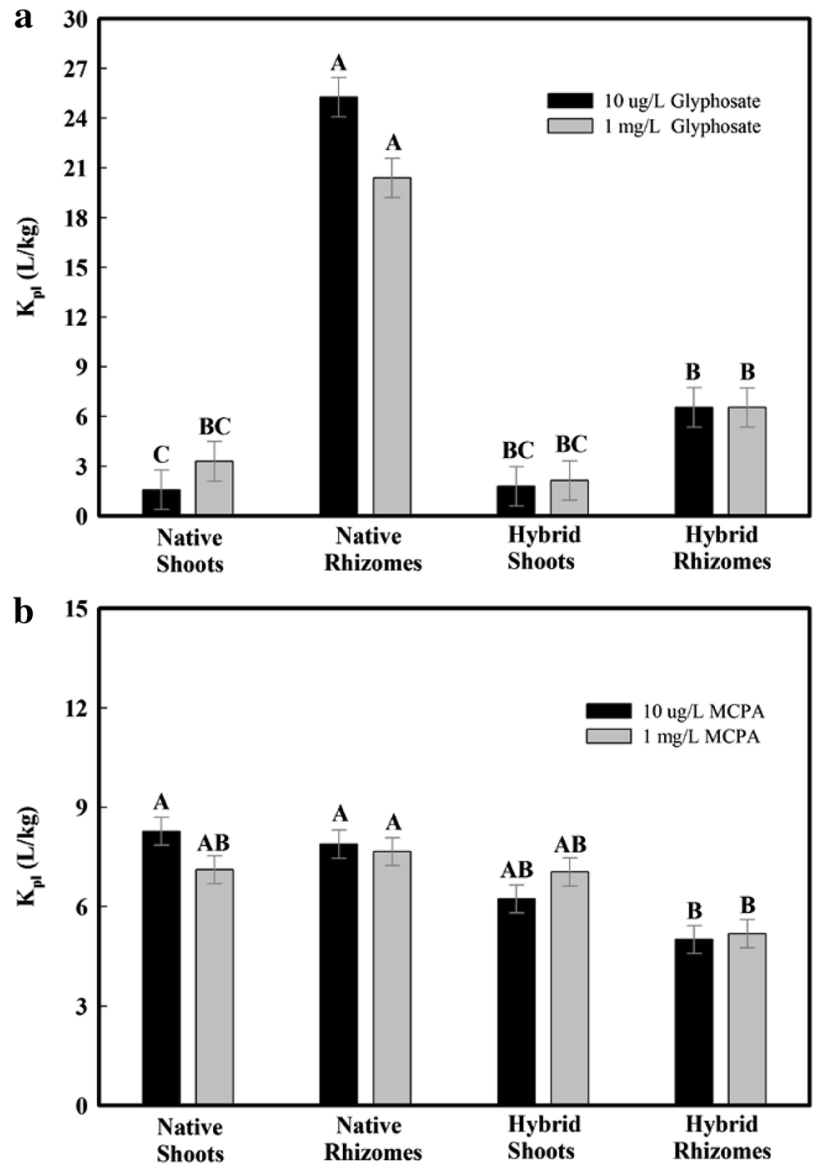

Fig. 2 Concentration dependent sorption study of a the plant-solution partition coefficient $\left(\mathrm{K}_{\mathrm{pl}}\right)$ of glyphosate and $\mathbf{b}$ the plant-solution partition coefficient $\left(\mathrm{K}_{\mathrm{pl}}\right)$ of MCPA after $48 \mathrm{~h}$; the $\mathrm{K}_{\mathrm{pl}}$ values were calculated by taking the average of the triplicate and the error bars indicated the standard deviation; the letters obtained from statistical analysis indicate the significance between the $\mathrm{K}_{\mathrm{pl}}$ values 
rhizomes, and than native or hybrid shoots (Fig. 1). In fact, at $0.5 \mathrm{~h}$, the glyphosate $\mathrm{K}_{\mathrm{pl}}$ values measured for native rhizomes were significantly larger than the glyphosate $\mathrm{K}_{\mathrm{pl}}$ values measured at any time step for hybrid rhizomes, and for native or hybrid shoots, including at $48 \mathrm{~h}$. For native rhizomes, glyphosate $\mathrm{K}_{\mathrm{pl}}$ values before $24 \mathrm{~h}$ were significantly smaller than after $24 \mathrm{~h}$, suggesting that glyphosate continued to partition into the native rhizomes over time. However, glyphosate sorption approached equilibrium between 24 and $48 \mathrm{~h}$ for the native rhizomes because there were no significant differences in glyphosate $\mathrm{K}_{\mathrm{pl}}$ values between these two time steps. In contrast, regardless of whether the initial solution contained $10 \mu \mathrm{g} / \mathrm{L}$ or $1 \mathrm{mg} / \mathrm{L}$ glyphosate, glyphosate absorption reached its maximum within $0.5 \mathrm{~h}$ for hybrid rhizomes, as well as for native and hybrid shoots. The reason was that shaking time had no significant impact on glyphosate $\mathrm{K}_{\mathrm{pl}}$ values for each of these plant treatments (Fig. 1). Also, for most time steps, there was no significant difference in glyphosate $\mathrm{K}_{\mathrm{pl}}$ values between hybrid rhizomes and native or hybrid shoots.

In a previous batch equilibrium study ( $\mathrm{Li}$ et al. 2005) that added organochlorines in solution to wheat and ryegrass seedlings, it reported that the passive nonfacilitated diffusion of pesticides was greater for rhizomes than shoots. More importantly, our results indicated that the absorption capacity of rhizomes can be species dependent, with the glyphosate absorption being significantly greater for rhizomes than shoots in case of native cattails, but with no significant differences in glyphosate absorption between rhizomes and shoots in case of hybrid cattails. As shown in our experiment, the time to equilibrium was also dependent on the type of plant materials studied and was rapid $(0.5 \mathrm{~h})$ for hybrid rhizomes, and for native and hybrid shoots but relatively slower (24-48 h) for native rhizomes. Equilibrium time is affected by the selection of sorbents and contaminants but is typically set at $24 \mathrm{~h}$ in most batch equilibrium studies, particularly in studies of pesticides sorption by soils (Kumari et al. 2016; Munira et al. 2016; Wauchope et al. 2002). In previous batch equilibrium studies, Mayakaduwa et al. estimated an equilibrium time of $4 \mathrm{~h}$ when glyphosate in solution was applied to woody biochar (Mayakaduwa et al. 2016). Ma and Wang et al. reported that the sorption of trichloroethylene by cattail roots required 4 days to reach equilibrium (Ma and Wang 2009).

For most herbicides, passive diffusion is an important process by which herbicides can move into roots and then translocate to action sites to adversely affect the plant. Our results indicated that the passive diffusion of glyphosate by rhizomes is less for hybrid than native cattail species, including at relatively large glyphosate concentrations in water. This suggests that hybrid cattails could be less sensitive to glyphosate concentrations in water than native cattails and perhaps explain recent observations in field settings (Linz and Homan 2011). For example, the U.S. Department of Agriculture's Wildlife Services has applied glyphosate to manage invasive hybrid cattails since last century. Nonetheless, hybrid cattail expansion has remained a critical challenge in North America because hybrid cattails demonstrate resistance towards glyphosate treatment (Linz and Homan 2011). Our experimental results, showing limited glyphosate absorption by hybrid shoots and rhizomes, may partially explain the resistance of hybrid cattails towards glyphosate treatment and the displacement of the native by the hybrid cattail, as sorption is an essential first step in treatment.

Sorption data for glyphosate and MCPA obtained at $48 \mathrm{~h}$ were further analyzed to help understand the different behaviors of the four cattail treatments at the two chosen concentrations (Fig. 2). Statistical analysis demonstrated that the effect of cattail treatments on $\mathrm{K}_{\mathrm{pl}}$ values was significant for both glyphosate and MCPA while the interaction effect

Table 2 Glyphosate sorption parameters (K) determined for a range of sorbents

\begin{tabular}{|c|c|c|c|c|c|c|c|}
\hline \multirow[t]{2}{*}{ Sorbent } & \multirow[t]{2}{*}{$\mathrm{K}(\mathrm{L} / \mathrm{kg})$} & \multicolumn{5}{|c|}{ Experimental conditions } & \multirow[t]{2}{*}{ Ref. } \\
\hline & & $\mathrm{pH}$ & Temperature $\left({ }^{\circ} \mathrm{C}\right)$ & Time (h) & $\begin{array}{l}\text { Initial } \\
\text { glyphosate } \\
\text { (mg/L) }\end{array}$ & $\begin{array}{l}\text { Solid/solution } \\
\text { ratio }(\mathrm{g} / \mathrm{mL})\end{array}$ & \\
\hline Native cattail rhizome & 25.3 and 20.4 & $\mathrm{n} / \mathrm{a}$ & 5 & 48 & 0.01 and 1 & $0.2 / 15$ & This study \\
\hline Hybrid cattail rhizome & 6.5 and 6.4 & $\mathrm{n} / \mathrm{a}$ & 5 & 48 & 0.01 and 1 & $0.2 / 15$ & This study \\
\hline Crop residue & $6.4-256$ & 7.4 & 20 & $\mathrm{n} / \mathrm{a}$ & 0.01 & $1 / 5.8$ & Cassigneul et al. (2016) \\
\hline Sandy loam soil & $0.6-78.5$ & $4.83-10.4$ & 22 & 24 & $0.03-67$ & $0.5 / 10$ & $\begin{array}{l}\text { de Jonge and Wollesen de } \\
\text { Jonge (1999) }\end{array}$ \\
\hline Soil mixture & $40-303$ & $5.2-8.1$ & Room temperature & 16 & $2-10$ & $10 / 50$ & Autio et al. (2004) \\
\hline Clay soil & $21-87$ & $6.3-7.5$ & Room temperature & 70 & $0.1-10$ & $1 / 10$ & Albers et al. (2009) \\
\hline Clay minerals & $8-138$ & $1.8-10.0$ & Room temperature & 1 & $100-200$ & $1 / 25$ & Glass (1987) \\
\hline Humic & $3-17$ & $2-7$ & Room temperature & 70 & $0.2-20$ & $0.01 / 1$ & Albers et al. (2009) \\
\hline Woody biochar & 88 & 5 & Room temperature & 4 & 20 & $1 / 1000$ & Mayakaduwa et al. (2016) \\
\hline
\end{tabular}


of concentrations and cattail treatments was significant for glyphosate but not for MCPA. For each of the four cattail treatments, results indicated no significant difference in $\mathrm{K}_{\mathrm{pl}}$ values under the two glyphosate concentrations, suggesting that the performances of native rhizome in absorbing glyphosate under the two concentrations were similar and that native cattail might be suitable for remediating glyphosate spills that would induce high glyphosate concentrations in water. In a previous batch equilibrium study (Hu et al. 2011), it reported that higher initial concentration of glyphosate resulted in much higher value in $\mu \mathrm{g}$ glyphosate/g sludge, which is comparable with our study when using cattail as a sorbent. Unlike the absorption of glyphosate by native rhizomes $\left(\mathrm{K}_{\mathrm{pl}}>20 \mathrm{~L} / \mathrm{kg}\right)$, MCPA $\mathrm{K}_{\mathrm{pl}}$ values remained at a relatively low level $(<8 \mathrm{~L} / \mathrm{kg})$ for all cattail treatments. However, similar to the glyphosate results, regardless of whether the initial solution contained $10 \mu \mathrm{g} / \mathrm{L}$ or $1 \mathrm{mg} / \mathrm{L}$ MCPA, native rhizomes demonstrated significantly greater $\mathrm{MCPA}_{\mathrm{pl}}$ values than hybrid rhizomes. Thus, it is possible that in addition to glyphosate, other herbicides are less likely to be absorbed by hybrid than native rhizomes.

Our results highlight the potential of native rhizomes as a sorbent for glyphosate, giving optimal mixing conditions. Table 2 compares our sorption results to the performance of other sorbents for glyphosate and indicates that the measured $\mathrm{K}_{\mathrm{pl}}$ values for native rhizomes are of the same magnitude as $\mathrm{K}$ values reported for other organic materials and soils.

Acknowledgements The primary author was a participant in a student exchange program funded by Knowledge Exchange program of the Netherlands Enterprise Agency and the International Institute for Sustainable Development (IISD) in Canada. Also, the authors acknowledge the Natural Sciences and Engineering Research Council of Canada (NSERC) (\#216906) for providing funding for carrying out the laboratory experiments.

Open Access This article is distributed under the terms of the Creative Commons Attribution 4.0 International License (http://creativecommons.org/licenses/by/4.0/), which permits unrestricted use, distribution, and reproduction in any medium, provided you give appropriate credit to the original author(s) and the source, provide a link to the Creative Commons license, and indicate if changes were made.

\section{References}

Albers CN, Banta GT, Hansen PE, Jacobsen OS (2009) The influence of organic matter on sorption and fate of glyphosate in soilcomparing different soils and humic substances. Environ Pollut 157:2865-2870. doi:10.1016/j.envpol.2009.04.004

Autio S, Siimes K, Laitinen P, Rämö S, Oinonen S, Eronen L (2004) Adsorption of sugar beet herbicides to Finnish soils. Chemosphere 55:215-226. doi:10.1016/j.chemosphere.2003.10.015

Benbrook CM (2016) Trends in glyphosate herbicide use in the United States and globally. Environ Sci Europe 28:1-15
Cassigneul A et al (2016) Fate of glyphosate and degradates in cover crop residues and underlying soil: A laboratory study. Sci Total Environ 545-546:582-590. doi:10.1016/j.scitotenv.2015.12.052

de Jonge H, Wollesen de Jonge L (1999) Influence of pH and solution composition on the sorption of glyphosate and prochloraz to a sandy loam soil. Chemosphere 39:753-763. doi:10.1016/ S0045-6535(99)00011-9

Donald DB, Syrgiannis J, Hunter F, Weiss G (1999) Agricultural pesticides threaten the ecological integrity of northern prairie wetlands. Sci Total Environ 231:173-181. doi:10.1016/ S0048-9697(99)00091-1

Dosnon-Olette R, Couderchet M, Eullaffroy P (2009) Phytoremediation of fungicides by aquatic macrophytes: toxicity and removal rate. Ecotoxicol Environ Saf 72:2096-2101. doi:10.1016/j. ecoenv.2009.08.010

Dosnon-Olette R, Couderchet M, El Arfaoui A, Sayen S, Eullaffroy $P$ (2010a) Influence of initial pesticide concentrations and plant population density on dimethomorph toxicity and removal by two duckweed species. Sci Total Environ 408:2254-2259. doi:10.1016/j.scitotenv.2010.01.057

Dosnon-Olette R, Trotel-Aziz P, Couderchet M, Eullaffroy P (2010b) Fungicides and herbicide removal in Scenedesmus cell suspensions. Chemosphere 79:117-123. doi:10.1016/j. chemosphere.2010.02.005

Farenhorst A, Andronak LA, McQueen RDA (2015a) Bulk deposition of pesticides in a Canadian city: part 1. Glyphosate and other agricultural pesticides. Water Air Soil Pollut 226:1-11

Farenhorst A, Andronak LA, McQueen RDA (2015b) Bulk deposition of pesticides in a Canadian city: part 2. Impact of malathion use within city limits. Water Air Soil Pollut 226:1-8

Franz JE, Mao MK, Sikorski JA (1997) Glyphosate: a unique global herbicide. American Chemical Society, Washington

Glass RL (1987) Adsorption of glyphosate by soils and clay minerals. J Agric Food Chem 35:497-500

Hiller E, Krascsenits Z, Čerňanský S (2008) Sorption of acetochlor, atrazine, 2, 4-D, chlorotoluron, MCPA, and trifluralin in six soils from Slovakia. Bull Environ Contam Toxicol 80:412-416

$\mathrm{Hu}$ YS, Zhao YQ, Sorohan B (2011) Removal of glyphosate from aqueous environment by adsorption using water industrial residual. Desalination 271:150-156. doi:10.1016/j.desal.2010.12.014

Ignatowicz K (2009) Selection of sorbent for removing pesticides during water treatment. J Hazard Mat 169:953-957. doi:10.1016/j. jhazmat.2009.04.061

Kumari KGID, Moldrup P, Paradelo M, Elsgaard L, de Jonge LW (2016) Soil properties control glyphosate sorption in soils amended with birch wood biochar. Water Air Soil Pollut 227:1-12

Li H, Sheng G, Chiou CT, Xu O (2005) Relation of organic contaminant equilibrium sorption and kinetic uptake in plants. Environ Sci Technol 39:4864-4870

Linz GM, Homan HJ (2011) Use of glyphosate for managing invasive cattail (Typha spp.) to disperse blackbird (Icteridae) roosts. Crop Prot 30:98-104

Ma X, Wang C (2009) Impacts of the physiochemical properties of chlorinated solvents on the sorption of trichloroethylene to the roots of Typha latifolia. Environ Pollut 157:1019-1023. doi:10.1016/j.envpol.2008.10.005

Mayakaduwa SS et al (2016) Equilibrium and kinetic mechanisms of woody biochar on aqueous glyphosate removal. Chemosphere 144:2516-2521

Messing PG, Farenhorst A, Waite DT, McQueen DAR, Sproull JF, Humphries DA, Thompson LL (2011) Predicting wetland contamination from atmospheric deposition measurements of pesticides in the Canadian Prairie Pothole region. Atmos Environ 45:7227-7234. doi:10.1016/j.atmosenv.2011.08.074

Messing P, Farenhorst A, Waite D, Sproull J (2013) Influence of usage and chemical-physical properties on the atmospheric 
transport and deposition of pesticides to agricultural regions of Manitoba. Canada Chemosphere 90:1997-2003. doi:10.1016/j. chemosphere.2012.10.071

Messing PG, Farenhorst A, Waite DT, Sproull JF (2014a) Air concentrations of currently used herbicides and legacy compounds in the Canadian prairies, subarctic, and arctic. J Environ Sci Health Part B 49:338-343

Messing PG, Farenhorst A, Waite DT, Sproull JF (2014b) Current-use herbicides in air as influenced by their estimated agricultural use at various distances from six sampling locations. Water Air Soil Pollut 225:1-10

Moore MT, Tyler HL, Locke MA (2013) Aqueous pesticide mitigation efficiency of Typha latifolia (L.), Leersia oryzoides (L.) Sw. and Sparganium americanum Nutt. Chemosphere 92:1307-1313. doi:10.1016/j.chemosphere.2013.04.099

Munira S, Farenhorst A, Flaten D, Grant C (2016) Phosphate fertilizer impacts on glyphosate sorption by soil. Chemosphere 153:471-477

Olette R, Couderchet M, Biagianti S, Eullaffroy P (2008) Toxicity and removal of pesticides by selected aquatic plants. Chemosphere 70:1414-1421. doi:10.1016/j.chemosphere.2007.09.016

Pearson D (2001) Surface-water systems use membranes to remove disinfection by-product precursors. Membr Technol 2001:4-7. doi:10.1016/S0958-2118(01)80213-5
Richards RP, Baker DB (1993) Pesticide concentration patterns in agricultural drainage networks in the lake Erie Basin. Environ Toxicol Chem 12:13-26

Schrübbers LC, Valverde BE, Strobel BW, Cedergreen N (2016) Glyphosate accumulation, translocation, and biological effects in Coffea arabica after single and multiple exposures European. $\mathrm{J}$ Agron 74:133-143. doi:10.1016/j.eja.2015.11.023

Shkinev VM (2001) On-line, multi-stage membrane systems for separating natural-water components and suspended solid materials. Membr Technol 2001:8-10. doi:10.1016/S0958-2118(01)80219-6

Trapp S, Miglioranza KSB (2001) Sorption of lipophilic organic compounds to wood and implications for their environmental fate. Environ Sci Technol 35:1561-1566

Waite DT, Sommerstad H, Grover R, Kerr L, Westcott ND (1992) Pesticides in ground water, surface water and spring runoff in a small saskatchewan watershed. Environ Toxicol Chem 11:741-748

Waite DT, Sommerstad H, Grover R, Kerr LA, Westcott ND, Irvine DG (1995) Atmospheric deposition of pesticides in a small southern saskatchewan watershed. Environ Toxicol Chem 14:1171-1175

Wauchope RD et al (2002) Pesticide soil sorption parameters: theory, measurement, uses, limitations and reliability. Pest Manag Sci $58: 419-445$ 